This item was submitted to Loughborough's Research Repository by the author.

Items in Figshare are protected by copyright, with all rights reserved, unless otherwise indicated.

\title{
Learning from the scientific legacies of W. Brutsaert and J.-Y. Parlange
}

\section{PLEASE CITE THE PUBLISHED VERSION}

http://dx.doi.org/10.1002/2013WR015147

\section{PUBLISHER}

John Wiley \& Sons (@ American Geophysical Union)

\section{VERSION}

VoR (Version of Record)

\section{PUBLISHER STATEMENT}

This work is made available according to the conditions of the Creative Commons Attribution-NonCommercialNoDerivatives 4.0 International (CC BY-NC-ND 4.0) licence. Full details of this licence are available at: https://creativecommons.org/licenses/by-nc-nd/4.0/

\section{LICENCE}

CC BY-NC-ND 4.0

\section{REPOSITORY RECORD}

Selker, John S., Graham C. Sander, Tammo Steenhuis, D. Andrew Barry, and William P. Kustas. 2019. "Learning from the Scientific Legacies of W. Brutsaert and J.-Y. Parlange". figshare. https://hdl.handle.net/2134/21408. 


\title{
Learning from the scientific legacies of $W$. Brutsaert and J.-Y. Parlange
}

\author{
John S. Selker, ${ }^{1}$ Graham Sander, ${ }^{2}$ Tammo Steenhuis, ${ }^{3}$ D. Andrew Barry, ${ }^{4}$ and William P. Kustas ${ }^{5}$ \\ Received 4 December 2013; accepted 6 December 2013.
}

[1] Though the essence of the scientific literature is to be a repository of unaffiliated truths, scientific advancement fundamentally stems from the insights and efforts of individuals. This dichotomy can hide exemplars for young scholars of how to contribute to scientific understanding. This section of Water Resources Research addresses eminently successful strategies for advancement of the science of hydrology by exploring the ramifications of the work from Drs. Wilfried Brutsaert and Jean-Yves Parlange, colleagues who made many of the most significant contributions to the understanding of hydrologic processes of the last 50 years. The generous scope of the special section follows the key areas of their contributions, but the content looks forward from their work. Important and novel results span solute transport, infiltration, streamflow generation, and evaporation.

Citation: Selker, J. S., G. Sander, T. Steenhuis, D. A. Barry, and W. P. Kustas (2014), Learning from the scientific legacies of W. Brutsaert and J.-Y. Parlange, Water Resour. Res., 50, doi:10.1002/2013WR015147.

[2] This issue traces key branches of the scientific legacy stemming from seminal contributions of two scientists who both recently retired from Engineering at Cornell University, Drs. Wilfried Brutsaert and Jean-Yves Parlange. The contributions included here make clear the explanatory power of the approach shared by Brutsaert and Parlange: the application of concise physically based representations of processes to understand myriad and intertwined elements of the water cycle. Underlying these works is the recognition that the most effective way to provide mechanistic understanding, while being guided by Ockham's razor, is to base analyses upon the governing equations for the formative processes. The parallel seen in their strategies extends also to the recognition these men received: both are members of the National Academy of Engineering, awardees of the AGU's Horton Medal and Horton Award, and AGU Fellows.

[3] Articles for the special section were sought in two formats: Reviews (focusing on original works of the Brutsaert and Parlange and developing the contemporary lines of discovery that emerged from these roots), and Letters, which are short contributions that offer focused single-

\footnotetext{
${ }^{1}$ Department of Biological and Ecological Engineering, Oregon State University, Corvallis, Oregon, USA.

${ }^{2}$ Department of Civil and Building Engineering, Loughborough University, Loughborough, UK.

${ }^{3}$ Department of Biological and Environmental Engineering, Cornell University, Ithaca, New York, USA.

${ }^{4}$ École Polytechnique Fédérale de Lausanne, Institut d'ingénierie de l'environnement, Vaud, Switzerland.

${ }^{5}$ USDA-ARS, Hydrology and Remote Sensing Laboratory, Beltsville, Maryland, USA.

Corresponding author: J. S. Selker, Department of Biological and Ecological Engineering, Oregon State University, 116 Gilmore Hall, Corvallis, OR 97331, USA. (selkerj@engr.orst.edu)
}

idea advancements on fields that were pioneered by Drs. Brutsaert and/or Parlange. The reviews include (working from the center of the earth outward): DiCarlo's presentation on the current state of understanding of fingered flow in unsaturated media; Lo and Sposito's presentation of propagation of acoustic waves in porous media; Assouline's survey of quantitative models for infiltration into soils; Troch et al.'s exploration of understanding the temporal behavior of recession of river flow through the lens of the Boussinesq Equation; Barry et al.'s survey of contaminant and sediment transport literature which grew from Parlange's approaches; and Dias' compilation outgrowths from Brutsaert's contributions to models and concepts in the parameterization of atmospheric turbulence. The letters were succinct articles which fit under the umbrella provided by the reviews, to render broad literature reviews redundant. Here we find original contributions inspired by work of Brutsaert and Parlange including: advancement of compact approaches to modeling infiltration (Triadis and Broadbridge); effects of capillary forces on water table fluctuations (Kong et al.); the validity of pan evaporation data to estimate landscape evapotranspiration (Brutsaert); and complementary relationships for estimation of evaporation (Crago and Qualls).

[4] While Parlange and Brutsaert have long been close friends and colleagues, and collaborated in hydrological research, it would be more accurate to describe them as working in close parallel than together for the majority of their contributions. The many cross citations of each other's results started in the 1970's, but it was not until 1987, after Parlange had moved to Cornell, that they coauthored their first joint paper. Seven papers joint papers followed. Undoubtedly, their mutual admiration and discussions together with Robert Miller enhanced their research endeavors and those of many others at Cornell University. Apart from their scientific insights, it is in this latter aspect, the direct and indirect effects on other 
researchers, which will be their most long-lived legacy. Their research records attest to the many cooperative research efforts they have undertaken, as suggested by long lists of coauthors. Second, their students and research collaborators are found in institutions worldwide, following lines of research derived from their interactions with Brutsaert and Parlange.
[5] We sincerely appreciate the extraordinary effort put forward by the authors of the papers in this issue, and the tireless assistance of the AGU staff in the preparation of this special section. Most of all, we give our deepest gratitude to Drs. Parlange and Brutsaert for providing the guidance and daily inspiration, which has immeasurably enriched our lives and the vigor of the advancement of hydrologic sciences. 